Sign Systems Studies 47(1/2), 2019, 88-104

\title{
Steps towards the natural meronomy and taxonomy of semiosis: Emon between index and symbol?
}

\author{
Kalevi Kull \\ Department of Semiotics \\ University of Tartu, \\ Jakobi 2, 51005 Tartu, Estonia \\ e-mail: kalevi.kull@ut.ee
}

\begin{abstract}
The main aim of this brief and purposely radical essay is to investigate further possibilities for empirical research in natural classification of semiosis (signs as wholes). Before introducing emon - a missing term in the taxonomy of signs - we make a distinction between the natural and artificial, and between the taxonomic and meronomic classifications of signs. Natural classifications or typologies are empirically based, while artificial classifications do not require empirical test. Meronomy describes the relational or functional structure of the whole (for instance triadic, circular, etc. composition of sign), while taxonomy categorizes individuals (individual signs). We argue that a natural taxonomy of signs can be based on the existence of different complexity of operations during semiosis, which implies different mechanisms of learning. We add into the taxonomy a particular type of signs - emonic signs, which are at work in imitation and social learning, while being more complex than indexes and less complex than symbols. Icons are related to imprinting, indexes to conditioning, emons to imitating, and symbols to conventions or naming. We also argue that the semiotic typologies could undergo large changes after the discovery of the proper mechanisms or workings of semiosis.
\end{abstract}

Keywords: icon; imitation; imprinting; mereology; natural classification; sign development; sign evolution; sign types; sign typology; social learning

Various signs exist. Signs exist - in the sense that they are unceasingly created; signs exist (only) in interpretation. Their classification can be either artificial or natural. A classification is natural if it is falsifiable, that is if there can be found 
at least potentially empirical arguments about the real classes to disprove or to improve the classification. Otherwise the classification is artificial. ${ }^{1}$

The classifications of signs ${ }^{2}$ used in contemporary general semiotics are very often those introduced by or stemming from the work of Charles Peirce. ${ }^{3}$ Can there be any observation that could disprove the Peircean ten-fold typology of signs? Or the 28 - or 66 -fold? ${ }^{4}$ No. Because these classifications are logically derived from the strictly triadic model, which by itself is logical and not empirical. Peircean typologies do not require an empirical research to be true. Thus, following the definition above, Peirce's classification of signs is artificial. ${ }^{5}$

Indeed, we can, in a way, compare the Peircean combinatoric taxonomy of signs with an algebraic classification of geometric figures. For instance, it makes sense to build the best algebraic classification of polyhedrons; this classification will certainly be usable for describing real forms. However, a study of real forms cannot help in improving the mathematical classification. In relation to the real variability of the forms of cells, or drawings, or signs, such classification is artificial.

This is not a critique of Peirce. Peirce's system is algebraic. It is based on his minimal model of sign, which is triadic, and the system derived from it is using the tacit assumption that a sign in all its complexifications and plurifications carries the basic minimal structure. As a result, in the Peircean system, the diversity of signs is a triversity.

1 Thus we do not include logical mistakes into the class of empirical arguments.

2 In this article we use the terms 'sign' and 'semiosis' as synonyms. This is based on the understanding that sign is - from one side - always a process, the sign process, sign process being commonly called semiosis, and - from the other side, dually - sign is always a (simultaneous) whole. Thus representamen, object and interpretant are parts of sign.

3 On Peirce's classification of signs, see the recent volume Queiros, Stjernfelt 2019.

4 About these Peircean classifications, see for instance Farias, Queiroz 2003. See also Peirce 2015.

5 One should notice that this seems to contradict to what Peirce himself said: "All classification, whether artificial or natural, is the arrangement of objects according to ideas. A natural classification is the arrangement of them according to those ideas from which their existence results. No greater merit can a taxonomist have than that of having his eyes open to the ideas in nature; no more deplorable blindness can afflict him than that of not seeing that there are ideas in nature which determine the existence of objects. The definitions of Agassiz will, at least, do us the service of directing our attention to the supreme importance of bearing in mind the final cause of objects in finding out their own natural classifications" (Peirce 1965: 103, CP 1.231). From here we can clearly see that Peirce's aim is natural classification. However, we also see that, for him, the natural classes are limited to the systems organized by final cause. Once we limit the existence of final cause with living (or organic wholes), then it follows that Peirce's concept of natural classification is inapplicable for non-living objects. Our definition of natural classification is not limited to the systems with final cause (as for instance, natural classification can be found also for chemical elements). Cf Liszka 2019. 
The problem of sign classification is not so simple, though. Semiosis is the process in which meaning arises or emerges. Meaning, by its nature, is logical and not a physiological or psychological phenomenon. However, on the biosemiotic level, it is logic in an extended sense. Peirce is describing the very fundamentals of logic, and because it is logic, one cannot test it via physiological or psychological experiments. This is the anti-psychologism of Peirce (Stjernfelt 2013). Semiosis as the process in which meaning emerges is also a system of physiological processes, although which physiological processes was unclear for Peirce, and is not entirely clear even now. Still, since Jakob von Uexküll's studies it has been clear that in order to make meaning, there should be a functional circle. Uexküll gave a certain physiological description to such functional circles. Functional circles were Uexküll's model of semiosis (Krampen 1997). While describing semiosis as functional circles is necessary, they do not yet provide sufficient conditions for semiosis. Deacon (2011) has demonstrated the importance of constraints regenerating constraints which work reciprocally, to which we added the necessity of incompatible codes in simultaneity, or choice (Kull 2015; 2018). Still, sufficient conditions for semiosis have not yet been properly described.

Two questions follow: First, can we get any evidence as to whether the signs as they exist in real life are indeed triadic, and never, for instance, tetradic, or septadic, or maybe indefinitely plural? Alternatively, perhaps signs are built so that their numerical characterization is irrelevant, or provide only an approximate model?

Secondly, should the general structure of sign be related to the existing classes of signs? In parallel, we might ask whether in biological classifications, the structure of species are related to the genera and familia that exist and the number of species these include? - The answer would obviously be 'no'. Why then should it be 'yes' in the classification of signs?

To seek a natural, not artificial, classification of signs, let us first introduce the distinction between two different types of classifications - meronomy and taxonomy of signs. This may help resolve some contradictions in the classifications found in the semiotic literature and may suggest a more systematic study of sign types. Following this distinction, we will describe a particular problem on sign typology found in semiotic literature, move to its solution, introduce the distinction between icon and emon, and finally address some earlier perspectives on the issue of semiotic typology. 


\section{Meronomy and taxonomy of signs}

Taxonomy and meronomy are two complementary approaches to classification or typology. Taxonomy joins individual objects into taxons (taxa) or classes, while meronomy divides a whole into merons or parts. ${ }^{6}$ For example, in biology, taxonomy deals with classification of species into genera, familia, etc., or individual communities into community types, while meronomy deals with classification (partitions) of an organism into organs, or an ecosystem into its functional components (see Table 1). By parallel, in semiotics taxonomy would describe the types of signs - or of texts, or narratives, or sentences, or organisms, while meronomy would describe the structure of signs - or of texts, narratives, sentences, organisms.

Mereology can be defined as the study of meronomies. Typology is commonly understood as the study of taxonomies. Both are dealing with classifications.

Table 1. A comparison between meronomy and taxonomy as the types of classifications.

\begin{tabular}{|l|l|l|}
\hline General procedure & \multicolumn{2}{|c|}{ Classification } \\
\hline Types of classification & meronomy & taxonomy \\
\hline Objects of classification & $\begin{array}{l}\text { parts of (e.g., sign or text } \\
\text { or organism as) a whole }\end{array}$ & $\begin{array}{l}\text { separate individuals (e.g., signs } \\
\text { or texts or organisms) or their } \\
\text { classes }\end{array}$ \\
\hline Main method & $\begin{array}{l}\text { study of functional } \\
\text { structure; describing the } \\
\text { archetype of the whole }\end{array}$ & $\begin{array}{l}\text { comparison and } \\
\text { homologization of structures } \\
\text { of individuals or classes }\end{array}$ \\
\hline Name of the units & meron & taxon \\
\hline $\begin{array}{l}\text { Product of classification } \\
\text { (e.g., of semiosis) }\end{array}$ & $\begin{array}{l}\text { structure (e.g., of } \\
\text { semiosis) }\end{array}$ & $\begin{array}{l}\text { types, classes (e.g., of } \\
\text { semioses) }\end{array}$ \\
\hline
\end{tabular}

Both meronomy and taxonomy can be either artificial or natural. Partition of a sign can be described by a model in which the parts do not correspond to the empirically discovered parts of a sign - in this case the partition is artificial. Still, it is also conceivable that the described merons of sign correspond to real parts then the meronomy is natural. The same is possible for taxonomies of signs - the

6 About these concepts, see for instance Meyen 1977, 1978; Chebanov 2017. On the applications of this distinction, see, e.g., Pavlinov 2016. The term 'meronomy' has been used especially by Russian scholars; it is the classification of parts of a whole as a result of mereological approach or partonomy (see, e.g., Calosi, Graziani 2014). A clear formulation of the opposition 'taxonomy/meronomy' together with 'taxon/meron' was developed by Sergej Meyen (1977). 
taxa in a taxonomy correspond to real taxa in the natural taxonomy, while there is no such correspondence in case of an artificial taxonomy.

\section{Whether meronomy can produce a taxonomy?}

Consider a functional partition of a simple whole into its natural parts. For instance, partitioning into three. Further, these parts, few in number, can also be partitioned using the same rule. Such two-level system is another whole, more complex, while still produced by the same partitioning principle. With this method, we can get the description of a large number of wholes, which are all products of the same partitioning principle. This is close to how Peirce produced the classes of signs. All taxonomic diversity of signs, according to his classification, imply triadic meronomic partitioning such that new forms are extension of Peirce's logical triadic archetype - from the archetype of the whole and its limited possibilities of construction.

As repeatedly stressed by Frederik Stjernfelt, Peirce's classification of signs is fundamentally a product of meronomic procedure (e.g., Stjernfelt 2000). It deals with the functional structure of sign (as semiosis) and its components. Its triadic principle is derived from the assumed logical structure of semiosis itself which cannot be dismissed in any of its parts. Since the division into merons is relational, the resulting Peircean classes of signs are necessarily interdependent. New sign types are generated in Peircean semiotics by partitioning or combining the small number of existing types.

Therefore, the possibility of a natural taxonomy of signs is not a trivial question - an artificial taxonomy may correspond to the natural taxonomy, and it may not. However, a natural taxonomy of signs is feasible if what is taken as the object of classification is not an artificial logical model of semiosis but features of sign relations that can be independently identified. This assumes that there can exist certain independent variability in subprocesses of semiosis as a whole.

How can we get to natural taxonomy of signs that can be tested? First, we should assume that there could emerge features of signs that are not logically deriveable from the basic model of sign. Second, we should assume the possibility of self-categorization or speciation of signs. Thus we should not assume that the whole taxonomy can be derived from the fundamental model or archetype of sign (although this does not exclude the possibility that the derivation from a good enough fundamental model may work). In this case, the testable natural classification will be possible. 
It is important to pay attention to the fact that at least for some aspects of semiosis, in certain limited groups of signs, rather good natural taxonomies already exist - for instance, in case of linguistic features of the elements of human languages, gestures, some groups of artefacts. However, and somewhat paradoxically, a general typology of signs has not yet achieved natural classification. As mentioned above, Peircean classification has not yet proven to be a natural classification and may not be until tools to demonstrate its correspondence to a testable classification are found.

In particular, we observe that the icon-index-symbol taxonomy has been used both as a logical product of meronomy and as a natural taxonomy. Peirce's typology is mainly mereological. Frederik Stjernfelt in his writings about Peirce interprets his typology as truly mereological. For Stjernfelt, the perception-action cycle is a natural proposition, with an argument-structure (even in a bacterium, indeed, "a very primitive" one); sign types are rather aspects of semiosis (Stjernfelt 2012). In contrast, Thomas Sebeok's six-fold typology of signs is rather naturally taxonomical (or at least semi-taxonomical). ${ }^{7}$ Also Terrence Deacon's typology in his Symbolic Species (Deacon 1997), however based on Peirce, is an attempt at a natural semiotic taxonomy. Deacon temporalizes sign types: these appear in ontogeny one emergent from another with a symbolic threshold zone separating human language from animal and vegetative sign systems.

Let us now explore classes of signs in pursuit of a natural taxonomy, not by updating Peircean classification which is the product of a particular meronomic model. Our approach below deals exclusively with a natural taxonomy of signs, which therefore should not be drawn from a fundamental sign model. Even accepting the Peircean triadic model of sign (triadicity belonging to meronomy), sign taxonomy can be achieved on an empirical basis without restrictions about the number of taxa.

\section{The icon-index-icon-symbol paradox}

In the semiotic literature we find variable and incompatible usage of the names of sign types. For some researchers, all signs are called symbols because they are at least to a certain extent arbitrary. For others, two main sign types exist - pictorial (as if continuous) signs are called icons, and textual (as if discrete) signs are called symbols. For still others, all signs have indexical aspects because they all refer to something.

7 This distinction has been characterized by Umberto Eco as the difference between Peirceologists and Peirceans; Eco identified himself with the latter (Eco 2014: 510). 
Nevertheless, icon, index, and symbol are very widely used both in semiotics and beyond as the three major sign types. That just three, and namely these three, became accepted as principal sign types has obviously happened due to Peirce's indirect influence. In parallel, oppositional (or differential, the binary) definition of meaning as supported by the Saussurean tradition works in the background and often modifies the usage of concepts. A contemporary semiotician is influenced by both. Here, let us focus on Peircean triads.

In the literature on semiotics, there are two traditions for dealing with basic three sign types. One that corresponds to Peirce, uses the sequence icon-indexsymbol. The other (e.g. Roland Barthes's), uses the sequence index-icon-symbol.

It seems that there is no single source for taking index as first. Barthes, when using the index-icon-symbol row (Barthes 1968: 37) refers to De lacte a la pensée (1942) by Henri Wallon, who might be one responsible for introducing this "reversed" sequence. Yet it is likely that several authors have used the index-iconsymbol row just independently, up to recent times (e.g., Sadowski 2009).

Thus, index is sometimes understood as preceding icon, and sometimes as following icon. That is what I call here the icon-index-icon-symbol paradox.

\section{A solution to the paradox: There are more sign types}

There are two obvious solutions to this paradox. The first, that either icon-indexsymbol or index-icon-symbol is wrong. The second, that there exist two rather different types of signs that have both been described as icon; that means, icon ${ }_{1}^{-}$ index-icon -symbol. $_{2}$.

I shall argue for the second solution. This means that both sequences of the triad have their reasonable uses. Simply, in case of index-icon-symbol, icon ${ }_{1}$ has not been noticed, while in case of icon-index-symbol, icon ${ }_{2}$ has been ignored. Accordingly, both had their restrictions.

It is understandable that for those researchers who focus on human sign systems and particularly on language, the primary icon $\left(\right.$ icon $\left._{1}\right)$ may be ignored. Such researchers would use the index-icon-symbol system, since the conditional learning resulting in conditioned reflexes and representing indexical relations is already so simple and elementary that there seems no reason to delve further. For example, imitation is an obvious candidate for iconicity. Since imitation is a more advanced capacity than conditional learning, it should stay after the indexicality (as icon $)_{2}$ in the temporalized sequence of sign types.

For instance, when Juri Lotman used the iconic-symbolic opposition, he did not speak about icons in the sense of Peirce or Eco. Lotman's icons are rather of 
the second type $\left(\right.$ icon $\left._{2}\right) .{ }^{8}$ The first type of icons $\left(\right.$ icon $\left._{1}\right)$ is rather close to what Eco referred to as 'hypoicon' (Eco 1999: 339).

Thus, the term 'icon' is used in two different taxonomic senses - as simpler than index, and as more complex than index. ${ }^{9}$ Indeed, resemblance is of two very different types. Simplifying, the first is based on indistinguishability, the second on similarity. The origin of these types of resemblance are either in the mechanism of recognition, or of imitation.

Despite the same names - icon, index, symbol - that Peirce is using in a different sense (i.e. not about signs as wholes, but as the relations between representamen and object, thus rather as merons), there is already a common tradition of using these names also as names for separate sign taxa. The additional distinctions introduced next may resolve some controversies.

\section{Emon - a missing term in the taxonomy of signs}

We add here the fourth type (taxon) - emonic signs, a sign type between index and

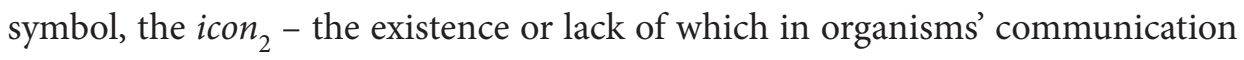
might be the reason for many behavioural differences. We make distinction between icons and emons and propose the sequence icon-index-emon-symbol. Doing so may resolve the ambiguous usage of the sequence index-icon-symbol instead of the original icon-index-symbol in some semiotic theories.

The word 'emon' as proposed here for the name of the sign type can be seen as a derivation from Greek ' $\eta \mu \omega v$ ' (' $\dot{\eta} \mu \tilde{\omega} v$ '), meaning 'company'. Occasionally, the term 'emon' has been used by Paul Nemirovsky to denote an element of emotional or aesthetic information (Nemirovsky 1999; Nemirovsky, Davenport 2002).

Emon may thus be related to emotions, empathy, imitation. Note that imitative learning assumes the capacity for analogization, and accordingly, the processes of amplification, which can possibly be identified with emotions. Perhaps the mechanisms of imitation employs mirror neurons (see Wiedermann 2003; Panksepp 2011). ${ }^{10}$

Most invertebrates cannot use emons due to the lack of the relevant mechanism of learning. Emons are acquired via imitation or social learning, and exist in

8 It should be added that index did not belong to Juri Lotman's typology of signs, except on some specialized occasions (e.g., Lotman 1990: 26-27, 103, 111). (I thank Silvi Salupere for this note.)

9 There exists an extensive semiotic literature and decades-long debate on the definition of iconicity (see for instance Eco 1999: 337ff).

10 Cf. also a distinction between imitation and emulation in Bandura 2009[1971]; some other aspects of emonic kind of resemblance, see Williams, Colling 2018. 
animals with emotions. Emonic semiosis would be present in vertebrates (birds and mammals), not invertebrates (insects). The transition from non-imitating to imitating animals would be the emonic threshold zone.

\section{Types of signs as related to the types of learning}

Semiosis as interpretation differs from deterministic (or even algorithmic) processes by the potential for innovation. This cleavage between the deterministic and innovative systems is pointing to the semiotic systems as learning systems.

Learning itself is not the same as semiosis. Learning happens if interpretation (semiosis) leaves a trace (a scaffold) that influences further interpretations. Learning fixes the link established in interpretation. ${ }^{11}$ If the form of the link requires different mechanisms of learning as dependent on the complexity of the link established, then certain correspondence between the types of semiosis (sign) and the mechanisms of learning should be the case.

The relationship between semiosis and learning can be described by the following steps or stages of this process:

(a) incompatibility: what can induce a functional change is an incongruence of existing sign relations, a semiotic conflict or untranslatability;

(b) innovation: if several options (possibilities) are available simultaneously, then a choice-like switch may take place; this solves the incompatibility (cf semiosis as problem-solving) by using one option and removing the rest; it establishes a connection (link), commonly with the help of existing scaffolding;

(c) habituation: this is how the new connection may become stabilized, and sometimes, partially inherited.

Learning means that a relatively stable mediator will be built that carries the link (bond) established in interpretation. In other words, learning is memory-building. Different complexity of the process demonstrates the possible relationship with different mechanisms of learning:

(i) iconic: if a link (the mediator) becomes reproduced, then this mediator, when linking, presents an operation of recognition; this would correspond to imprinting as a form of learning;

(ii) indexical: if the connection is linking two separate recognition events, then it will produce preferably the bonds (relations) between those things that are co-present or correlated - thus the link presents the operation of association; this would correspond to conditioning as a form of learning;

11 On some additional aspects of semiotic learning see Kull 2018. 
(iii) emonic: if it is possible to link to a link, then it tends to produce a linkage that models (imitates) the whole pattern of a regular situation, producing a representation; this would correspond to imitating as a form of learning;

(iv) symbolic: if it is possible to interlink representations, then it implies the possibility to compose any patterns (thus providing full open-endedness); also, since at that level, the patterns produced can be isolated (detached, independent) from the regularities; this would correspond to conventioning or naming as a form of learning;

Such typology describes the different levels of morphological forms as constructed (designed) by different types of semiosis as logical operations:

(i) vegetative level: recognition, iconic - swarms, territories, lines, trees, bodies;

(ii) animal level: conditioning, indexical - centres, circles, spaces, homes;

(iii) emotional level: imitation, emonic - family groups, social customs;

(iv) cultural level: replacement, symbolical - times, narratives, calculations, recombinations.

While this typology is stemming from the Peircean approach, its stress on natural taxonomy more than on mereology may require a wholly different terminology, in order to avoid unnecessary polysemy. Moreover, there could be more taxa in this taxonomy than four. For instance, we could additionally distinguish between two types of recognition (in an analogy with the difference between iconic qualisign and iconic sinsign in Peirce), resulting in the following taxonomy of signs:

(ia) percon, based on elementary recognition;

(ib) nexon, based on categorization (collective recognition by the neural tissue);

(ii) junction, based on association;

(iii) emon, based on imitation (mimicking);

(iv) nomon, based on composition (arranging, combination).

\section{Discussion: Some comments on earlier works on emons}

The idea about the existence of emon-like signs has appeared in the works of several semioticians. Below we point out some of these.

(1) Artifice

The importance to add a fourth type of sign was also noticed by Roman Jakobson. He wrote: 
The "artifice" is to be added to the triad of semiotic modes established by Peirce. This triad is based on two binary oppositions: contiguous/similar and factual/ imputed. The contiguity of the two components of the sign is factual in the index but imputed in the symbol. Now, the factual similarity which typifies icon finds its logically foreseeable correlative in the imputed similarity which specifies the artifice, and it is precisely for this reason that the latter fits into the whole which is now forever a four-part entity of semiotic modes. (Jakobson 1985[1975]: 215; Jakobson 1980: 22; our emphasis in the final clause, K. K.)

W. C. Watt (1981: 430) has commented:

Jakobson provides the occasional shaft of light into Peirce's murky domain, as when [Jakobson 1980: 11] he observes that a signans may refer to its signatum by means of contiguity, similarity, and/or convention: that is, respectively by an index, an icon, and/or a symbol [notice the order! - K. K.]. He later [Jakobson 1980: 22] analyses these binarily (contiguous/similar and factual/imputed) and fills the missing cell in the resulting $2 \times 2$ matrix by adding the "artifice", or metaphor, which resembles the icon in asserting a similarity between signans and signatum but differs in that in the artifice the similarity is imputed rather than factual as in the icon. This new semiotic tetrachotomy should sharpen discussion among those so inclined.

Here Jakobson (1985[1975]: 214-215) uses the term 'artifice' in reference to Gerard Manly Hopkins, who wrote:

The artificial part of poetry, perhaps we shall be right to say all artifice, reduces itself to the principle of parallelism. The structure of poetry is that of continuous parallelism [...]. But parallelism is of two kinds necessarily - where the opposition is clearly marked, and where it is transitional rather or chromatic. [...] To the marked or abrupt kind of parallelism belong metaphor, simile, parable, and so on, where the effect is sought in likeness of things, and antithesis, contrast, and so on, where it is sought in unlikeness. To the chromatic parallelism belong gradation, intensity, climax, tone, expression (as the word is used in music) [...]. (Hopkins 1959[1865]: 84-85; our emphasis, K. K.)

When speaking about artifice, Hopkins as well as Jakobson assign this only to arts. Largely coinciding to our observations about emon, the features of this type of sign are clearly such that its manifestation is certainly not limited to arts.

It should also be noted that Jakobson uses a pair of binary oppositions in his definition - despite a reference to Peirce. Binary structures, of course, were not at all what Peirce himself would use. Yet, binary oppositions are more of a meronomic than of a taxonomic kind. Therefore, for emon being a taxonomic unit, it would be misleading just to identify it with artifice. 
(2) Synesthon

William C. Watt $(1987 ; 1999)$ introduced the sign type that he calls 'synesthon', while calling this switch from the Peircean triadic classification to a tetrachotomy a 'neo-Peircean approach'. He placed synesthons (that evoke similar feelings) between index and symbol (Watt 1987: 339). Later, however, Watt (2011: 369) hypothesizes that "there are really only two fundamental kinds of signs, the synesthon [...] and symbol".

\section{(3) Meme}

Emon as the sign based on imitation may seem to have some similarity with Richard Dawkins' concept of meme. However, there are several fundamental reasons why these two are deeply different. The most important difference between them concerns the basic logical incongruence - meme is defined as based on replication (copying), while emon is defined as based on interpretation process. ${ }^{12}$ From this many consequences follow. The replication process leads to the incorporation of meme (as an analogue of gene) into the neo-Darwinian model. The interpretation process as the one on which imitation is based, makes emon a concept of non-neo-Darwinian theory. Another aspect is that many writings in memetics mix up the symbolic and presymbolic level of signs, even if they mean that memes are signs (which they often do). And last but not least, by the end of the internet journal of memetics itself, it became clear to some proponents of memetics themselves that meme is not a good term. Later, the term has been used to denote only the forms of epidemic distribution (Marino 2015).

\section{(4) Returning to Peirce: the rhematic iconic legisign}

Peirce's ten-fold taxonomy of signs includes three kinds of iconic signs. These are iconic qualisign, iconic sinsign, and iconic legisign (all three being rhemes). The first two (iconic qualisign and iconic sinsign) are simpler than indexical signs, while the iconic legisign is, in a certain sense, situated between index and symbol if mapped on the three-fold taxonomy of signs. The ten classes in Peircean taxonomy cannot be naturally ordered into a linear sequence, therefore such mapping is not unambiguous. Also, as said above, it is not entirely clear whether we could take Peircean classification as natural. However, the features of iconic legisign fit well what we have described here as emon.

\footnotetext{
12 Even if meme has been defined as produced by imitation, the innovative aspect of interpretation that is characteristic of imitation has not been taken into account.
} 


\section{Conclusion}

One of the big problems that inhibits the development of semiotics is the absence of agreement on the basic terminology of sign taxonomy. Semioticians seldom agree on identification of sign types. Semiotic textbooks are often incompatible in their sign typologies. However, a basic sign typology is indispensable to semiotics. The Peircean typologization of signs into ten classes - despite the clear definitions of these taxa - has been applied rather seldom in practical semiotic studies. More often a much simpler classification is used. The aim of our essay was to build a mediating "scaffold" for moving from a simple three-fold typology of signs into a more detailed but still obvious natural taxonomy. We did it by describing the type of signs we called emons. Together with this, linking the sign types to the types of learning mechanisms, we tried to demonstrate a way to develop a natural taxonomy of signs that would open further possibilites for empirical semiotic research and the post-Peircean taxonomies.

We did not include the definition of sign (semiosis) itself in this work. If the model of sign will be substantially modified (for instance, see some hints towards this in Brandt 2016 and Kull 2018), then the implications can affect the analysis above. Indeed, we expect that both meronomy and taxonomy of signs will be fundamentally changed, when we shall truly understand the conditions in which sign emerges. However, we hope that the distinctions described above will open up a space for further studies in the field of typology of semiosis.

Finally - can we really break the three, the triadic model of semiosis? Will this mean the non-acceptance of Peircean semiotics? No. This will just be a next step post-Peircean (bio)semiotics ${ }^{13} \cdot{ }^{14}$

13 The idea about post-Peircean biosemiotics has been expressed recently by Alin Olteanu (2019) and Claudio J. Rodríguez.

14 Acknowledgements. A part of this paper was presented at a semiotic congress in Nanjing (Kull 2014). I thank Frederik Stjernfelt and Göran Sonesson for helpful discussions and Jeremy Sherman for improving the text. This work was supported by the Estonian Research Council grant PRG314. 


\section{References}

Bandura, Albert 2009[1971]. Analysis of modeling processes. In: Bandura, Albert (ed.), Psychological Modeling: Conflicting Theories. New Brunswick: Aldine Transaction, 1-62.

Barthes, Roland 1968[1964]. Elements of Semiology. New York: Hill and Wang.

Brandt, Per Aage 2016. Deixis and the ontology of signs: Two essays towards a clarification. Language and Semiotic Studies 2(4): 116-133.

Calosi, Claudio; Graziani, Pierluigi (eds.) 2014. Mereology and the Sciences: Parts and Wholes in the Contemporary Scientific Context. (Synthese Library 371.) Cham: Springer.

Chebanov, Sergey 2017. Meronomiya S. V. Mejena: k 40-letiyu formulirovaniya. Lethaea rossica 14: 64-92. [Чебанов, Сергей В. 2017. Мерономия С. В. Мейена: к 40-летию формулирования. Lethaea rossica 14: 64-92.]

Deacon, Terrence 1997. The Symbolic Species: The Co-evolution of Language and the Brain. New York: W.W. Norton \& Company.

- 2011. Incomplete Nature: How Mind Emerged from Matter. New York: W. W. Norton \& Company.

Eco, Umberto 1999. Kant and the Platypus: Essays on Language and Cognition. San Diego: The Harvest Book, Harcourt.

- 2014. From the Tree to the Labyrinth: Historical Studies on the Sign and Interpretation. Cambridge: Harvard University Press.

Farias, Priscila Lena; Queiroz, João 2003. On diagrams for Peirce's 10, 28, and 66 classes of signs. Semiotica 147: 165-184.

Hopkins, Gerard Manley 1959[1865]. Poetic diction. In: House, Humphry (ed.), The Journals and Papers of Gerard Manley Hopkins. London: Oxford University Press, 84-85.

Jakobson, Roman 1980. The Framework of Language. (Michigan Studies in the Humanities 1.) Michigan: Michigan Slavic Publications.

- 1985[1975]. A glance at the development of semiotics. In: Jakobson, Roman, Selected Writings VII: Contributions to Comparative Mythology: Studies in Linguistics and Philology, 1972-1982. (Rudy, Stephen, ed.) Berlin: Mouton Publishers, 199-218. [Also in Jakobson 1980: 1-29.]

Krampen, Martin 1997. Models of semiosis. In: Posner, Roland; Robering, Klaus; Sebeok, Thomas A. (eds.), Semiotics: A Handbook on the Sign-theoretic Foundations of Nature and Culture. Vol. 1. Berlin: Walter de Gruyter, 247-287.

Kull, Kalevi 2014. A taxonomy and evolution of semiosis as based on the mechanisms of learning: Emonic signs. In: Wang, Yongxiang; Yu, Hongbing (eds.), Traversing the Mental and the Artistic Worlds (Proceedings of the 11th World Congress of the IASS/AIS. Nanjing Normal University, 5-9 October 2012; vol. 1). Nanjing: Hohai University Press, 3-9.

- 2015. Semiosis stems from logical incompatibility in organic nature: Why biophysics does not see meaning, while biosemiotics does. Progress in Biophysics and Molecular Biology 119(3): 616-621.

- 2018. Choosing and learning: Semiosis means choice. Sign Systems Studies 46(4): 452-466.

Liszka, James 2019. Reductionism in Peirce's sign classifications and its remedy. Semiotica 228: 153-172.

Lotman, Yuri M. 1990. Universe of the Mind: A Semiotic Theory of Culture. London: I. B. Tauris. 
Marino, Gabriele 2015. Semiotics of spreadability: A systematic approach to internet memes and virality. Punctum 1(1): 43-66.

Meyen, Sergej V. 1977. Taksonomiya i meronomiya [Taxonomy and meronomy]. In: Povarennyh, Aleksandr S.; Onoprienko, Valentin I. (eds.), Voprosy metodologii v geologicheskih naukah. Kiev: Naukova Dumka, 25-33. [Мейен, Сергей В. 1977. Таксономия и мерономия. In: Поваренных, Александр С.; Оноприенко, Валентин И. (eds.), Вопросы методологии в геологических науках. Kiev: Naukova Dumka, 25-33.]

- 1978. Osnovnye aspekty tipologii organizmov [Main aspects of organisms' typology]. Zhurnal obshchej biologii [Journal of General Biology] 39(4): 495-508. [Мейен, Сергей В. Основные аспекты типологии организмов. Журнал общей биологии 39(4): 495-508.]

Nemirovsky, Paul 1999. Aesthetic Forms of Expression as Information Delivery Units. MSc thesis. Cambridge: Massachusetts Institute of Technology.

Nemirovsky, Paul; Davenport, Glorianna 2002. Aesthetic forms of expression as information delivery units. In: McKevitt, Paul; Ó Nualláin, Seán; Mulvihill, Conn (eds.), Language, Vision, and Music: Selected Papers from the 8th International Workshop on the Cognitive Science of Language Processing, Galway, Ireland 1999. (Advances in Consciousness Research.) Amsterdam: John Benjamins, 255-270.

Olteanu, Alin 2019. Multiculturalism as Multimodal Communication: A Semiotic Perspective. (Numanities - Arts and Humanities in Progress 9.) Cham: Springer.

Panksepp, Jaak 2011. BrainMind, mirror neurons, empathy, and morality: What to believe about the evolution of the social mind. The Evolutionary Review: Art, Science, Culture 2: 38-49.

Pavlinov, Igor Ya. (ed.) 2016. Aspects of Biodiversity. (Archives of Zoological Museum of Moscow State University 54.) Moscow: KMK Scientific Press.

Peirce, Charles Sanders 1965. Collected Papers of Charles Sanders Peirce. Vols. 1-2. (Hartshorne, Charles; Weiss, Paul, eds.) Cambridge: The Belknap Press of Harvard University Press.

- 2015. Division of signs. Sign Systems Studies 43(4): 651-662.

Queiros, João; Stjernfelt, Frederik (eds.) 2019. Peirce's Extended Theory and Classifications of Signs. (Semiotica 228.) Berlin: De Gruyter Mouton.

Sadowski, Piotr 2009. From Interaction to Symbol: A Systems View of the Evolution of Signs and Communication. Amsterdam: John Benjamins Publishing Company.

Stjernfelt, Frederik 2000. Mereology and semiotics. Sign Systems Studies 28: 73-97.

- 2012. The evolution of semiotic self-control: Sign evolution as the ongoing refinement of the basic argument structure of biological metabolism. In: Schilhab, Theresa; Stjernfelt, Frederik; Deacon, Terrence (eds.), The Symbolic Species Evolved. (Biosemiotics 6.) Dordrecht: Springer, 39-63.

- 2013. The generality of signs: The actual relevance of anti-psychologism. Semiotica 194: 77-109.

Wallon, Henri 1942. De lacte à la pensée: essai de psychologie comparée. Paris. Flammarion.

Watt, William C. 1981. The framework of language: Roman Jakobson. American Anthropologist 83: 430-431.

- 1987. Sign and signifex. In: Steele, Ross; Threadgold, Terry (eds.), Language Topics: Essays in Honour of Michael Halliday. Vol. 1. Amsterdam: John Benjamins Publishing Company, 333-346. 
- 1999. The synesthon. In: Carr, Gerald F.; Harbert, Wayne; Zhang, Lihua (eds.), Interdigitations: Essays for Irmengard Rauch. New York: Peter Lang, 535-541.

- 2011. Birth of a notion. In: Cobley, Paul; Deely, John; Kull, Kalevi; Petrilli, Susan (eds.), Semiotics Continues to Astonish: Thomas A. Sebeok and the Doctrine of Signs. (Semiotics, Communication and Cognition 7.) Berlin: De Gruyter Mouton, 365-370.

Wiedermann, Jirí 2003. Mirror neurons, embodied cognitive agents and imitation learning. Computing and Informatics 22(6): 545-559.

Williams, Daniel; Colling, Lincoln 2018. From symbols to icons: The return of resemblance in the cognitive neuroscience revolution. Synthese 195(5): 1941-1967.

\section{Шаги к естественной мерономии и таксономии семиозиса: эмон между индексом и символом?}

Цель этой краткой и намеренно радикальной статьи состоит в том, чтобы взглянуть на некоторые возможности для эмпирического исследования естественной классификации семиозиса (знака как целого). Прежде чем вводить эмон - отсутствующий термин в таксономии знаков - мы проводим различие между естественными и искусственными, а также между таксономической и мерономической классификациями знаков. Естественные классификации или типологии основаны на эмпирических данных, в то время как искусственные классификации не требуют тестирования. Мерономия описывает реляционную или функциональную структуру целого (например, триадный, пентадный и т. д. состав знака), в то время как таксономия классифицирует индивидов (отдельные знаки). Утверждаем, что естественная таксономия знаков может основываться на существовании различной сложности операций семиозиса, что, в свою очередь, подразумевает разные механизмы обучения. Мы добавляем новый тип знаков к используемой таксономии - эмонические знаки, которые являются основой для подражания и социального обучения, будучи более сложными, чем индексы, и менее сложными, чем символы. Иконы связаны с импринтингом, индексы с упражнением, эмоны с имитацией и подражанием, а символы с соглашением и именованием. Однако следует также иметь в виду, что семиотические типологии могут претерпеть большие изменения после открытия надлежащих механизмов работы семиозиса.

\section{Mõned sammud semioosi loomuliku meronoomia ja taksonoomia poole: eemon indeksi ja sümboli vahel?}

Käesoleva lühikese ja teadlikult radikaalse kirjutise eesmärk on vaadelda mõningaid võimalusi semioosi (ehk märgi kui terviku) loomuliku klassifikatsiooni empiiriliseks uurimiseks. Selleks määratleme esmalt erinevused loomuliku ja kunstliku ning meronoomilise ja taksonoomilise klassifikatsiooni vahel. Loomulikud klassifikatsioonid põhinevad empiirikal, kunstlikud klassifikatsioonid aga testimist ei eelda. Meronoomia kirjeldab terviku funktsionaalset struktuuri, taksonoomia aga kategoriseerib indiviidide hulka. Väidame, et märkide loomulik taksonoomia saab tugineda semioosi operatsioonide erinevale keerukusele, millega omakorda seostuvad erinevad õppimismehhanismid. Lisame kasutatavale taksonoomiale uue märgitüübi - eemoni ehk emoonilise märgi, mis on aluseks imiteerimisele ja sotsiaalsele õppimisele. Eemon on 


\section{Kalevi Kull}

keerukam kui indeks, kuid lihtsam kui sümbol. Ikoonid seostuvad vermimisega, indeksid harjutamisega, eemonid jäljendamisega ning sümbolid kokkuleppimise ja nimetamisega. Tuleb aga ühtlasi silmas pidada, et semioosi tõeliste mehhanismide avastamisel saavad olema olulised tagajärjed ka märkide tüpoloogiale. 